\title{
Physiological, physical, and morpho-anatomical changes in Libidibia ferrea ((Mart. ex Tul.) L.P. Queiroz) seeds after overcoming dormancy ${ }^{1}$
}

\author{
Antônio César Batista Matos²*, Glauciana da Mata Ataíde ${ }^{3}$, \\ Eduardo Euclydes de Lima e Borges ${ }^{2}$
}

\begin{abstract}
Seed dormancy is a phenomenon that affects the distribution of plant species in time. However, it may slow germination and consequently hinder seedling production in nurseries. Many seeds of forest species of the Fabaceae family, such as Libidibia ferrea (Brazilian ironwood), have physical dormancy caused by impermeability of the seed coat to water. Therefore, the aim of this study was to evaluate the physiological, physical, and morpho-anatomical characteristics of $L$. ferrea seeds before and after application of different treatments for overcoming dormancy. We evaluated the imbibition curves, germination percentage, germination speed index (GSI), the force required to puncture the micropylar region, and morphoanatomical changes through images obtained from a scanning electron microscope (SEM) before and after application of treatments for overcoming dormancy. L. ferrea seeds immersed in sulfuric acid show a triphasic pattern of imbibition. The required force to puncture the micropylar region of $L$. ferrea seeds is less for both the treatment with boiling water and for treatments with sulfuric acid. In addition, the required force to puncture the micropylar region decreases during imbibition of the seeds after application of sulfuric acid. The time of application of sulfuric acid influences the thickness of the material removed from the macrosclereid layer of the seed coat.
\end{abstract}

Index terms: Libidibia ferrea ((Mart. ex Tul.) L.P. Queiroz), forest seeds, physical dormancy.

\section{Alterações fisiológicas, físicas e morfo-anatômicas em sementes de Libidibia ferrea após superação de dormência}

\begin{abstract}
RESUMO - A dormência de sementes é um fenômeno que influencia a distribuição das espécies de vegetais no tempo. Porém, pode retardar a germinação, e consequentemente, dificultar a produção de mudas em viveiros. Muitas sementes de espécies florestais da família Fabaceae, como Libidibia ferrea (pau-ferro), apresentam dormência física causada pela impermeabilidade do tegumento à água. Portanto, o objetivo neste trabalho foi avaliar as características fisiológicas, físicas e morfo-anatômicas das sementes de L. ferrea antes e após aplicação de diferentes tratamentos para superação de dormência. Avaliaram-se as curvas de embebição, a porcentagem de germinação, o índice de velocidade de germinação, a força requerida para ruptura da região micropilar e as alterações morfo-anatômicas por meio de imagens obtidas de microscópio eletrônico de varredura antes e após a aplicação de tratamentos para superação de dormência. Sementes de L. ferrea imersas em ácido sulfúrico apresentam padrão trifásico de embebição. A força de ruptura da região micropilar de sementes de L. ferrea é menor tanto para o tratamento com água fervente quanto para os tratamentos com ácido sulfúrico. Além disso, a força necessária para ruptura da região micropilar diminui durante a embebição das sementes após aplicação de ácido sulfúrico. O tempo de aplicação de ácido sulfúrico influencia na espessura removida da camada de macroesclereídios do tegumento das sementes.
\end{abstract}

Termos para indexação: pau-ferro, sementes florestais, dormência física.

\section{Introduction}

Conservation of natural resources in their different levels has been a concern for humanity in recent decades. Among these, forest resources stand out as they significantly

${ }^{1}$ Submitted on $09 / 10 / 2014$. Accepted for publication on 11/12/2014. ${ }^{2}$ Departamento de Engenharia Florestal, UFV, 36570-000 - Viçosa, MG, Brasil. contribute to the biodiversity of any community, region, or country. The development of research is fundamental in coming to know the factors that affect the survival of forest species and that thus allow the formation of strategies for germplasm conservation.
${ }^{3}$ Departamento de Silvicultura, UFRRJ, 23895000 - Seropédica, RJ, Brasil. *Corresponding author <batistamatos@gmail.com> 
The propagation of forest species is basically carried out through sexual propagation, a feature that may ensure or expand the genetic base of the next plant populations. However, many native tree species exhibit seed dormancy, which may hinder the planning of nurseries and seedling production for reforestation programs.

Among the types of dormancy, physical dormancy is known to occur in approximately 18 families of angiosperms, including Fabaceae (Baskin and Baskin, 2014). The impermeability of the seed coat to water is caused by the presence of one or more layers of elongated cells, macrosclereids that form a palisade layer that is filled with chemical products that repel water (Baskin, 2003; Turner et al., 2005; Venier et al., 2012; Bewley et al., 2013).

Libidibia ferrea ((Mart. ex Tul.) L.P. Queiroz), formerly known as Caesalpinia ferrea and popularly known as pau ferro (ironwood), is an initial secondary species, semideciduous, and is part of the vegetation of the Lowland Semideciduous Seasonal Forest, Dense Ombrophilous Forest, Caatinga (Xeric Shrubland)/ Dry Forest and in the highland marsh (Carvalho, 2003). In Brazil, it is found in the states of Piauí, Ceará, Rio Grande do Norte, Paraíba, Pernambuco, Alagoas, Sergipe, Bahia, Espírito Santo, Minas Gerais, and Rio de Janeiro (Carvalho, 2003; OliveiraFilho, 2006). The wood is very resistant and used in civil construction, carpentry, urban forestry, landscaping, and in recovery of degraded areas (Lorenzi, 2002; Carvalho, 2003). Propagation of the species is mainly through seeds; however, $L$. ferrea seeds exhibit dormancy, caused by the impermeability of the seed coat to water.

There are various studies related to seed analysis in this species (Teixeira et al., 2004; Medeiros Filho et al., 2005; Lima et al., 2006; Biruel et al., 2007; Câmara et al., 2008; Teixeira and Machado, 2008; Coelho et al., 2010). Thus, the aim of this study was to evaluate the physiological, physical, and morpho-anatomical characteristics of the L. ferrea seeds before and after application of different treatments for overcoming dormancy.

\section{Material and Methods}

L. ferrea seeds collected from five trees in October and November 2011 in the region of Viçosa, Minas Gerais, Brazil were used. During processing, immature, deteriorated, and damaged seeds were eliminated, and the remaining seeds from all the trees were mixed and then placed in cold storage $\left(5{ }^{\circ} \mathrm{C} / 60 \%\right.$ relative humidity - $\left.\mathrm{RH}\right)$ for 4 months, at which time the experiments began.

A completely randomized experimental design was used, with four treatments and five replications. For the study in overcoming dormancy, the following treatments were used: TC - control seeds (without overcoming dormancy); TA seeds placed in boiling water for one minute; T20 - seeds immersed in concentrated (97\%) sulfuric acid for 20 minutes; and T40 - seeds immersed in concentrated (97\%) sulfuric acid for 40 minutes. After application of the treatments with sulfuric acid, the seeds were washed in running water and then dried for 24 hours.

Initially, the moisture content of the seed lot was determined through the laboratory oven method at $105 \pm 3{ }^{\circ} \mathrm{C}$ (Brasil, 2009) using five replications of 20 whole seeds. The percent of water gain $(\%)$ was calculated in relation to the initial weight of the seeds of each treatment. Before beginning imbibition, the seeds were weighed on a digital balance with precision of $0.0001 \mathrm{~g}$, and then they were placed for imbibition on a Petri dish lined with two sheets of filter paper moistened with distilled water, and kept under constant light at the temperature of $25^{\circ} \mathrm{C}$. The seeds were weighed at two-hour intervals for the first 12 hours and then at twelve-hour intervals until reaching 50\% germination or up to the 10th day after the beginning of imbibition. Before each weighing, the surface of the seeds was dried with absorbent paper and after the weighings, the seeds were once more placed in the Petri dishes. Five replications of 20 seeds were used for each treatment.

The dry seeds (control) and those subjected to the treatments for overcoming dormancy were immersed in a $0.5 \%$ Captan $^{\circledR}$ solution for three minutes and then placed on two sheets of paper moistened with $4.0 \mathrm{~mL}$ of distilled water on Petri dishes and kept in a BOD type germinator at the temperature of $25^{\circ} \mathrm{C}$ for 10 days. Daily evaluations were made, with the germination criteria being growth of the radicle ( $\geq 1 \mathrm{~mm}$ ). To calculate the germination speed index (GSI), the formula proposed by Maguire (1962) was used: GSI = , where $n_{i}$ is the number of seeds per day and $t_{i}$ is the time (days). Each treatment consisted of five replications of 20 seeds.

The force required to puncture the micropylar region of the L. ferrea seeds was measured as described by Anese et al. (2011). A probe with a hemispherical tip and a diameter of $0.30 \mathrm{~mm}$ was placed on the load cell. The puncture force was measured using a texture analyzer (Stable Micro Systems) from the Meat Analysis Laboratory of the Food Technology Department of the Universidade Federal de Viçosa - UFV, Viçosa, MG, Brazil. Dry seeds were used (control) and seeds at 24 hours after application of the treatments. In addition, puncture force was also evaluated during seed germination after definition of the best treatment for overcoming dormancy at 24-hour intervals. The force required to puncture the micropylar region was expressed in Newtons $(\mathrm{N})$, used as a parameter of mechanical resistance to elongation of the embryo during 
seed germination. The resistance data was obtained from the mean of 30 individual seeds taken at random after each aforementioned interval.

For scanning electron microscope (SEM) analyses, seed samples of the four treatments for overcoming dormancy, which are not conductors of electrical current, were first coated through vacuum precipitation with a micrometric film of gold in a metallizer (Sputter Coating Attachment), model SCA 010, and then analyzed in a microscope LEO brand, model 1430 VP (Zeiss, Jena, Germany). The coating strictly followed the contours of the material so as not to result in false images of the topography of the sample.

Data were interpreted statistically by analysis of variance. After that, they were subjected to regression analysis and the results of required puncture force and GSI were subjected to the Scott-Knott test at $5 \%$ probability. There was no need for transformation of the data according to the tests of normality and homogeneity of variances. The software Statistica 8.0 (2009) and Sisvar 5.3 were used (Ferreira, 2011).

\section{Results and Discussion}

The Libidibia ferrea seeds were collected at a moisture content of $8.48 \%$. In the imbibition curves, it was seen that the treatments for overcoming dormancy affected water absorption, and weight gain of the seeds increased in the treatments with sulfuric acid (Figure 1). The evolution of imbibition for treatments with acid formed a triphasic curve. In seeds of the control group (without overcoming dormancy), the lowest water absorption speed was seen, and these seeds did not reach phase II. This fact explains the low percent of germination, which was $2 \%$ during the period of observation (Figure 2). In addition, a low value for GSI $(0.07)$ was also observed, which was equal to the treatment with boiling water for 1 minute, and different from the other treatments (Table 1). The low germination caused by the impermeability of the seed coat to water was evident. This impermeability is quite common in seeds of the species of the Fabaceae family (Baskin and Baskin, 2005).

It was observed that the seeds immersed in boiling water for one minute reached phase II in around 60 hours of imbibition (Figure 1). However, the percent of germination was only $2 \%$ (Figure 2 ) and the GSI was 0.04 , these parameters being equal to that of the control group and different from the other treatments (Table 1). Possibly the hot water weakened the cell structures of the seed coat and allowed the entry of water through greater cell expansion. However, it caused irreversible damage to the embryo due to the high temperature, impeding seed germination, as also reported by Alves et al. (2000), Alves et al. (2004), Coelho et al. (2010), and Costa et al. (2010), who worked with seeds from Cassia excelsa Schrad, Bauhinia monandra Britt., Bauhinia divaricata L., Caesalpinia ferrea Mart. ex Tul, and Adenanthera pavonina $\mathrm{L}$., respectively.

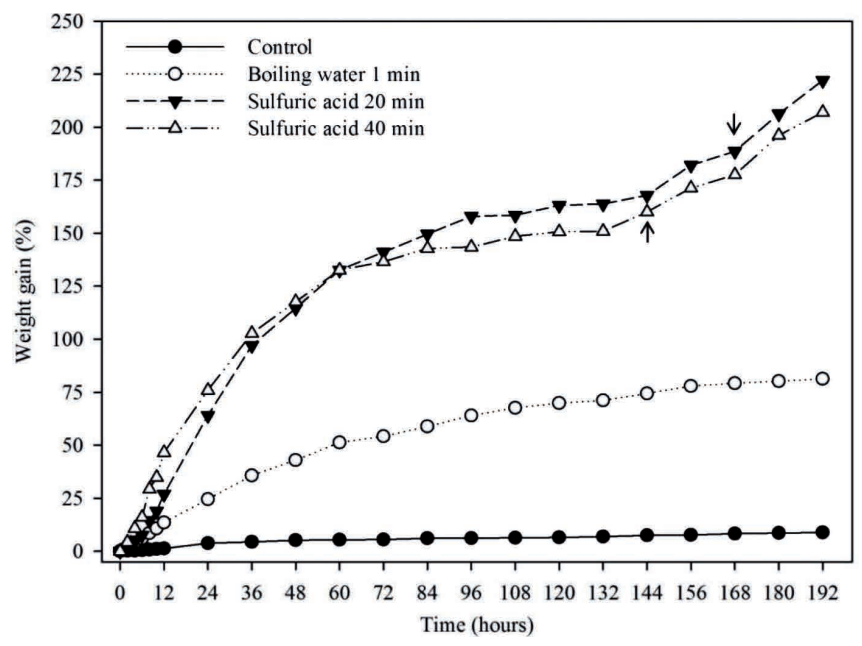

Figure 1. Imbibition curves of Libidibia ferrea seeds after application of different treatments for overcoming dormancy. Arrows indicate the beginning of phase III of imbibition.

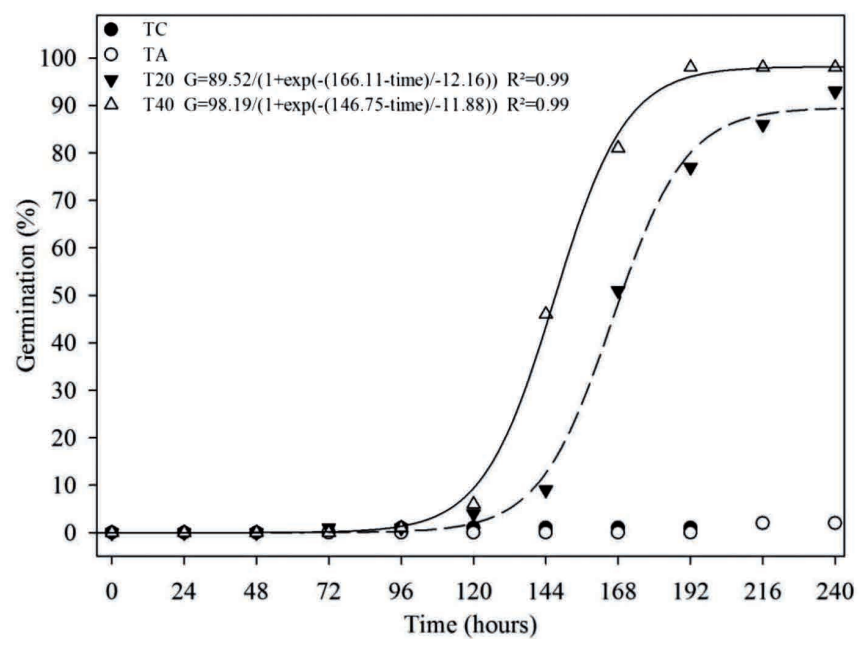

Figure 2. Germination of Libidibia ferrea seeds after application of different treatments for overcoming dormancy. TC - control seeds (without overcoming dormancy); TA - seeds placed in boiling water for one minute; T20 - seeds immersed for 20 minutes in sulfuric acid; T40 - seeds immersed for 40 minutes in sulfuric acid. 
Table 1. Force required to puncture $(\mathrm{N})$ the micropylar region and germination speed index (GSI) of Libidibia ferrea seeds after application of different treatments for overcoming dormancy.

\begin{tabular}{ccc}
\hline Treatments & Force $(\mathrm{N})$ & GSI \\
\hline TC & $15.61 \mathrm{a}^{*}$ & $0.07 \mathrm{c}^{*}$ \\
TA & $13.48 \mathrm{~b}$ & $0.04 \mathrm{c}$ \\
T20 & $13.78 \mathrm{~b}$ & $2.54 \mathrm{~b}$ \\
T40 & $12.33 \mathrm{~b}$ & $3.01 \mathrm{a}$ \\
\hline
\end{tabular}

TC - control seeds (without overcoming dormancy); TA - seeds placed in boiling water for one minute; T20 - seeds immersed for 20 minutes in sulfuric acid; T40 - seeds immersed for 40 minutes in sulfuric acid.

*Mean values followed by the same letters in the column do not differ among themselves by the Scott-Knott test at 5\% probability.

For the seeds immersed in sulfuric acid for 20 minutes, a triphasic pattern of imbibition was observed. From 48 to 60 hours were necessary for phase I, in which the seeds reached approximately a $120 \%$ weight gain. The seeds remained in phase II for 120 hours and reached 180\% weight gain, and after 168 hours, the seeds reached phase III (Figure 1). The L. ferrea seeds after immersion in sulfuric acid for 20 to 40 minutes reached a maximum percentage of $89 \%$ and $98 \%$ germination in 240 hours, respectively (Figure 2). For the GSI, different values were observed between the aforementioned treatments -2.54 for the treatment with sulfuric acid for 20 minutes and 3.01 for the treatment with sulfuric acid for 40 minutes (Table 1). In relation to the latter treatment, the triphasic pattern of imbibition was observed, requiring 48 to 60 hours for phase I, 96 hours for phase II, and 144 hours for phase III (Figure 1). In addition, for this treatment, superior results were observed for the germination speed index when compared to the others (Table 1). Biruel et al. (2007) observed that the treatments with immersion of $C$. ferrea seeds in sulfuric acid from 15 to 30 minutes were the most effective for overcoming physical dormancy and, consequently, greater values were observed for germination and GSI. Medeiros Filho et al. (2005) and Coelho et al. (2010) observed that hot water was not effective for overcoming dormancy of the same species as observed in this study.

For the required puncture force test carried out soon after the treatments, it was observed that the control treatment (dry seeds without overcoming dormancy) obtained a mean value of $15.61 \mathrm{~N}$, which was different from the value of the other treatments for overcoming dormancy (Table 1). Mean values found were $13.48 \mathrm{~N}$ for boiling water, $13.78 \mathrm{~N}$ for sulfuric acid for 20 minutes, and $12.33 \mathrm{~N}$ for sulfuric acid for 40 minutes. The seeds without previous treatment exhibited intact seed coat structures, the required force to pass through this physical barrier was greater, which characterizes the hardness of the seed coat of this species. The puncture force was measured during germination of $L$. ferrea seeds after immersion in sulfuric acid for 40 minutes, and it may be observed that over the period of seed imbibition, the required force decreased until reaching mean values of $1.0 \mathrm{~N}$ after 96 hours of imbibition, at which time germination began (Figure 3). After 144 hours of imbibition, the required force decreased to $0.3 \mathrm{~N}$, at which point $43 \%$ germination was observed.

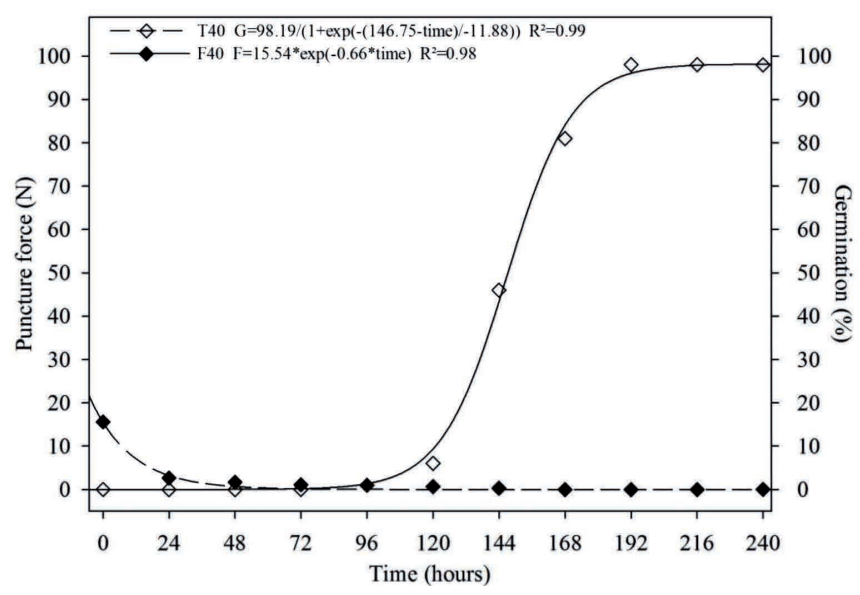

Figure 3. Germination and force required to puncture the micropylar region of Libidibia ferrea seeds after application of sulfuric acid for 40 minutes. T40 germination of seeds immersed in sulfuric acid for 40 minutes; F40 - required puncture force after immersion of seeds in sulfuric acid for 40 minutes.

Restrictive structures such as the endosperm and the seed coat generate impediments to potential embryo growth. The main changes in mechanical resistance, especially in the endosperm, occur during seed imbibition. Studies like those described by Silva et al. (2004), Anese et al. (2011), and Morris et al. (2011) showed the force imposed by the micropylar endosperm on Solanum lycocarpum and Lepidium sativum seeds, respectively. According to these authors, the micropylar endosperm progressively weakens during germination, mainly through the action of the endo- $\beta$-mannanase enzyme, one of the enzymes responsible for the degradation and weakening of the micropylar endosperm. In addition, Silva et al. (2004) also observed similar action of the cellulase enzyme. The increase in endo- $\beta$-mannanase and cellulase activity coincided with the decrease in puncture force of the micropylar endosperm. According to the results of this study, these enzymes cited may be acting on the structures of restriction to embryo growth of L. ferrea seeds during hydration, weakening them and allowing germination of the species. 
Based on the images obtained by SEM, it may be observed that $L$. ferrea seeds have a surface composed of lines of cracks (Figures 4A and 4B). Figure 4C represents the overall view of the radial section, where the testa, endosperm, and cotyledon may be distinguished. In Figure 4D, magnified 850 times, it is possible to view a layer of compacted cells (palisade layer of macrosclereids).

Boiling water for one minute was not effective in bringing about morpho-anatomical changes in the seeds (Figures 5A and
5B). However, according to the imbibition curve (Figure 1), there was loosening of the seed coat since weight gain reached $80 \%$ up to 192 hours and the puncture force of the micropylar region was less, in contrast with the seeds without previous treatment, which reached only $8 \%$ weight gain up to 192 hours, and required greater force to puncture the micropylar region. Thus, the low percent of germination brought about by this treatment is related to the damages to the embryo caused by thermal stress.
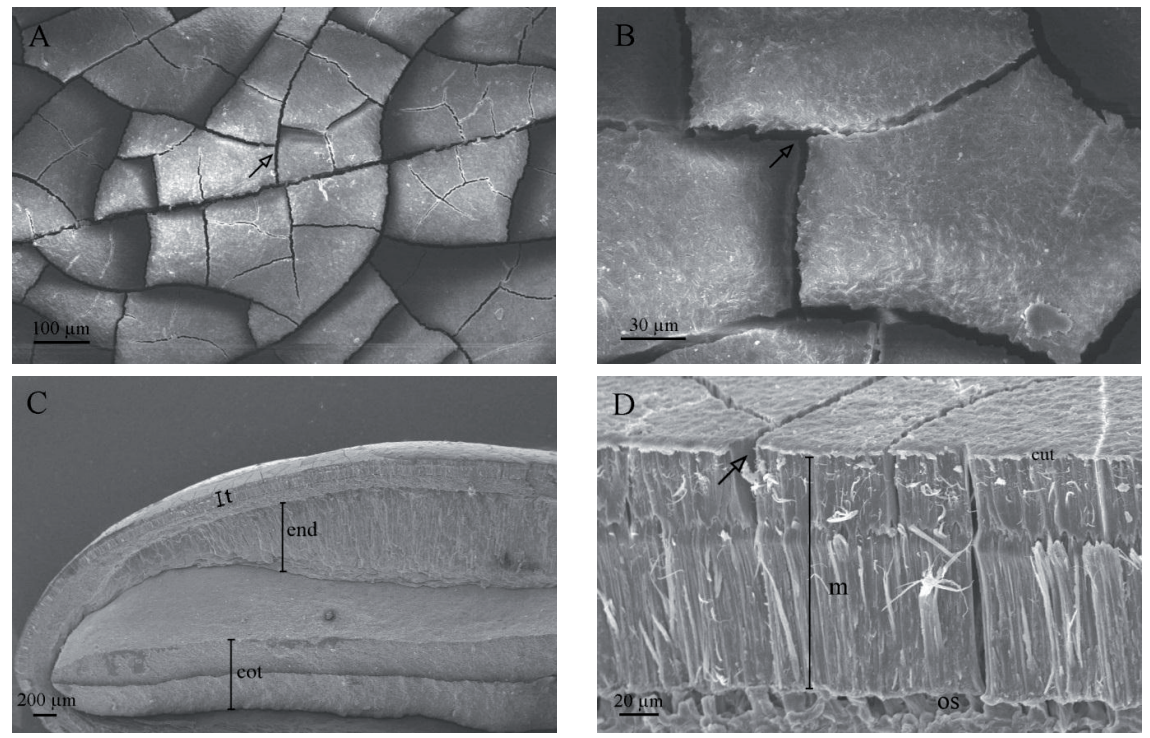

Figure 4. Images obtained from the scanning electron microscope (SEM) at different levels of magnification for dry Libidibia ferrea seeds without treatment. A and B - images of the surface. Arrows indicate the cracks on the surface of the seed coat; $\mathrm{C}$ and $\mathrm{D}$ - images of the radial section ( $\mathrm{t}$ - testa; end - endosperm; cot - cotyledons; cut - cuticle; $\mathrm{m}$ - palisade layer of macrosclereids; os - osteosclereids.) Arrow indicates the crack.
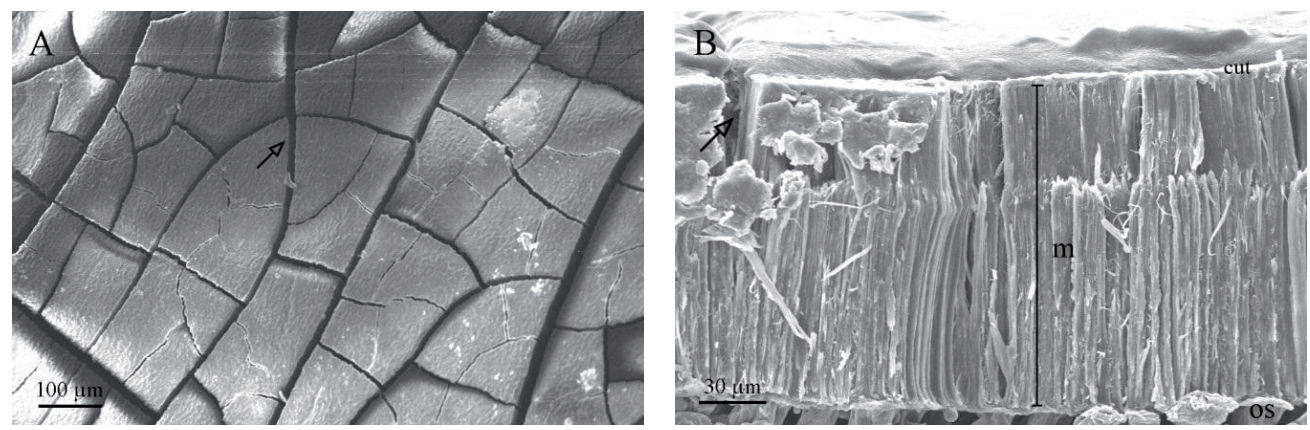

Figure 5. Images obtained from the scanning electron microscope (SEM) at different levels of magnification for Libidibia ferrea seeds immersed in hot water for one minute. A - image of the surface. Arrow indicates the cracks on the surface of the seed coat; B - image of the radial section ( $\mathrm{m}$ - palisade layer of macrosclereids; cut - cuticle; os osteosclereids). Arrow indicates the crack.

The images of the surface and the radial section of the treatments with acid for 20 and 40 minutes indicate anatomical changes. In the image of the surface (Figure 6A), corresponding to the acid treatment for $20 \mathrm{~min}$, it may be observed that the entire surface area of the seed has a wrinkled appearance and that the thickness of the cracks increased. In 
Figure $6 \mathrm{~B}$, it may be observed that part of the palisade layer was removed by the sulfuric acid, allowing imbibition of the seeds and, consequently, an increase in the germination percentage. The seeds immersed in sulfuric acid for 40 minutes had double the removal of the palisade layer when compared to those immersed for $20 \mathrm{~min}$, and also exhibited points with new quite significant cracks in the portion underneath the macrosclereid layer (Figures 7A and 7B). This treatment led to greater speed of germination, correlating the values found for the required force to puncture the structures restricting the growth of the L. ferrea embryo. Pozitano and Rocha (2011) observed that the wax layer was totally removed in Senna macranthera seeds immersed in sulfuric acid for 20 minutes, which favored water absorption and seed germination. For the results of that study, it was seen that the main layer of impermeability to water was the palisade layer.
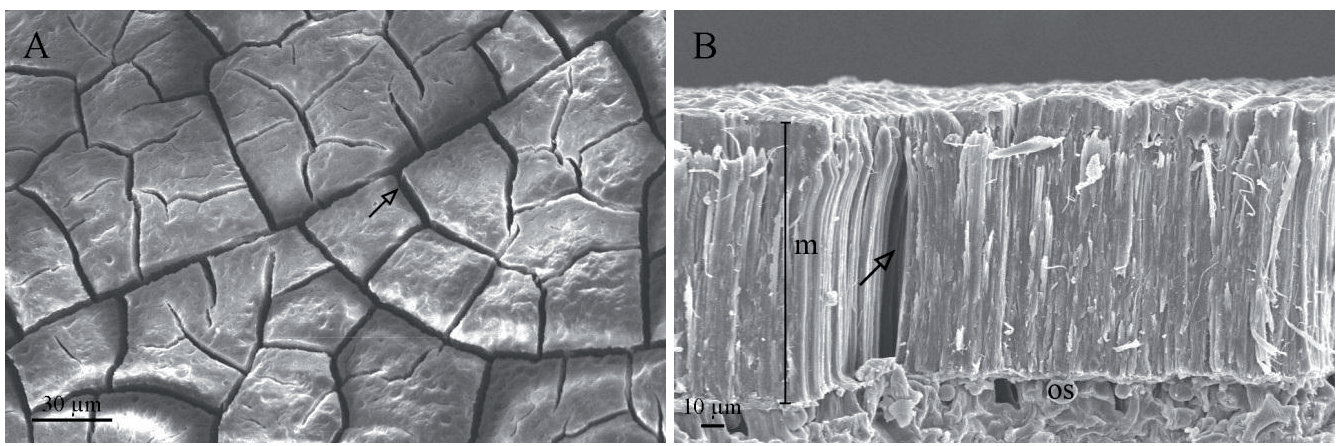

Figure 6. Images obtained from the scanning electron microscope (SEM) at different levels of magnification for Libidibia ferrea seeds immersed in sulfuric acid for 20 minutes. A - image of the surface. Arrow indicates the cracks on the surface of the seed coat. B - image of the radial section ( $\mathrm{m}$ - palisade layer of macrosclereids; os - osteosclereids). Arrow indicates the crack.
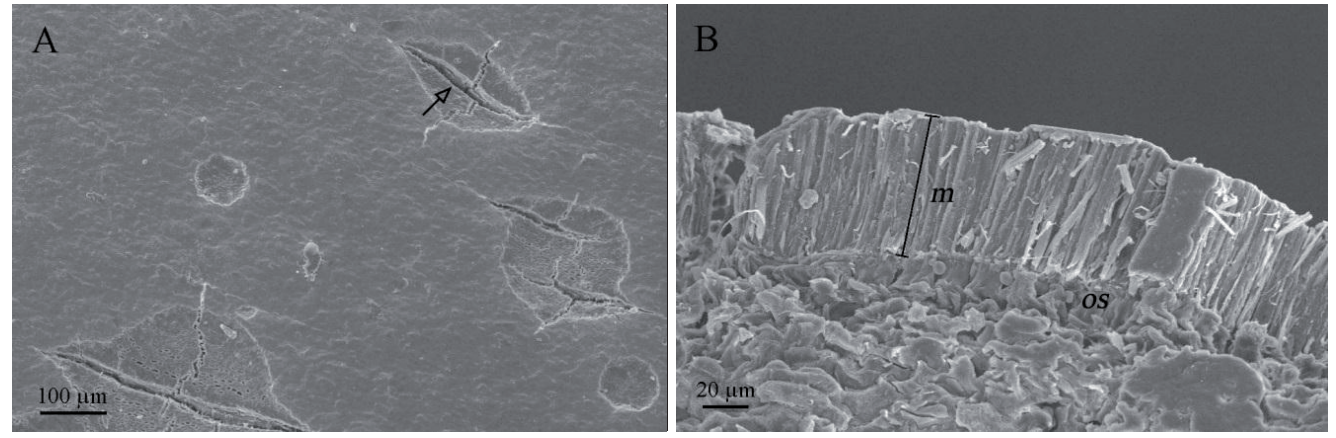

Figure 7. Images obtained from the scanning electron microscope (SEM) at different levels of magnification for Libidibia ferrea seeds immersed in sulfuric acid for 40 minutes. A - image of the surface. Arrow indicates the appearance of new cracks. B - image of the radial section ( $\mathrm{m}$ - palisade layer of macrosclereids; os - osteosclereids).

\section{Acknowledgments}

To Conselho Nacional de Desenvolvimento Científico e Tecnológico (CNPq) for the master scholarship to the first author.

\section{Conclusions}

L. ferrea seeds immersed in sulfuric acid exhibit a triphasic pattern of imbibition during hydration in water at the temperature of $25^{\circ} \mathrm{C}$.
The required force to puncture the micropylar region of $L$. ferrea seeds is less for both the boiling water treatment and the treatments with sulfuric acid.

The required force to puncture the micropylar region of $L$. ferrea seeds decreased during seed imbibition after application of sulfuric acid for 20 and 40 minutes.

The time of application of sulfuric acid affected the thickness of the macrosclereid layer removed from the seed coat of L. ferrea seeds. 


\section{References}

ALVES, A.U.; DORNELAS, C.S.M.; BRUNO, R.L.A.; ANDRADE, L.A.; ALVES, E.U. Superação da dormência em sementes de Bauhinia divaricata L. Acta Botânica Brasílica, v.18, n.4, p.871-879, 2004. http://www.scielo.br/ pdf/abb/v18n4/23222.pdf

ALVES, M.C.S.; MEDEIROS-FILHO, F.; ANDRADE-NETO, M.; TEOFILO, E.M. Superação de dormência em sementes de Bauhinia monandra Britt. e Bauhinia ungulata L.- Cesalpinoideae. Revista Brasileira de Sementes, v.22, n.2, p.139-144, 2000. http://www.abrates.org.br/revista/ artigos/2000/v22n2/artigo19.pdf

ANESE, S.; SILVA, E.A.A.; DAVIDE, A.C.; FARIA, J.M.R.; SOARES, G.C.M.; MATOS, A.C.B.; TOOROP, P.E. Seed priming improves endosperm weakening, germination, and subsequent seedling development of Solanum lycocarpum St. Hil.. Seed Science and Technology, v.39, p.125-139, 2011. http:// www.ingentaconnect.com/content/ista/sst/2011/00000039/00000001/art00011

BASKIN, C.C. Breaking physical dormancy in seeds - focussing on the lens. New Phytologist, v.158, p.229-232, 2003. http://onlinelibrary.wiley.com/ doi/10.1046/j.1469-8137.2003.00751.x/pdf

BASKIN, C.C.; BASKIN, J.M. Seed dormancy in trees of climax tropical vegetation types. Tropical Ecology, v.46, n.1, p.17-28, 2005. http://www. tropecol.com/pdf/open/PDF_46_1/46102.pdf

BASKIN, C.C.; BASKIN, J.M. Seeds: ecology, biogeography, and evolution of dormancy and germination, 2nd ed. San Diego, CA, USA: Academic/ Elsevier, 2014. 1600p.

BEWLEY, J.D.; BRADFORD, K.J.; HILHORST, H.W.M.; NONOGAKI, H. Seeds: physiology of development, germination and dormancy. New York: Springer, 2013. 392p

BIRUEL, R.P.; AGUIAR, I.B.; PAULA, R.C. Germinação de sementes de pau-ferro submetidas a diferentes condições de armazenamento, escarificação química, temperatura e luz. Revista Brasileira de Sementes, v.29, n.3, p.134141, 2007. http://www.scielo.br/pdf/rbs/v29n3/a18v29n3.pdf

BRASIL. Ministério da Agricultura, Pecuária e Abastecimento. Regras para análise de sementes. Ministério da Agricultura, Pecuária e Abastecimento. Secretaria de Defesa Agropecuária. Brasília: MAPA/ACS, 2009. 395p. http:// www.agricultura.gov.br/arq_editor/file/2946_regras_analise_sementes.pdf

CÂMARA, F.A.A.; TORRES, S.B.; GUIMARÃES, I.P.; OLIVEIRA, M.K.T.; OLIVEIRA, F.A. Biometria de frutos e sementes e superação de dormência de jucá (Caesalpinia ferrea Mart. ex Tul (Leguminosae - Caesalpinoideae). Caatinga, v.21, n.4, p.172-178, 2008. http://periodicos.ufersa.edu.br/revistas/ index.php/sistema/article/viewFile/827/426

CARVALHO, P.E.R. Espécies arbóreas brasileiras. Brasília: Embrapa Informação Tecnológica; Colombo: Embrapa Florestas, 2003. 1039p.

COELHO, M.F.B.; MAIA, S.S.S.; OLIVEIRA, A.K.; DIÓGENES, F.E.P. Superação da dormência tegumentar em sementes de Caesalpinia ferrea Mart ex Tul. Revista Brasileira de Ciências Agrárias, v.5, n.1, p.74-79, 2010. http://www.agraria.pro.br/sistema/ index.php?journal $=$ agraria\&page $=$ article $\&$ op $=$ view $\&$ path []$=$ agraria v5ila570\&path[] $=622$

COSTA, P.A.; LIMA, A.L.S.; ZANELLA, F.; FREITAS, H. Quebra de dormência em sementes de Adenanthera pavonina L. Pesquisa Agropecuária Tropical, v.40, n.1, p.83-88, 2010. http://www.revistas.ufg.br/index.php/pat/ article/viewArticle/4092
FERREIRA, D.F. Sisvar: a computer statistical analysis system. Ciência e Agrotecnologia, v.35, n.6, p.1039-1042, 2011. http://www.scielo.br/pdf/ cagro/v35n6/a01v35n6.pdf

LIMA, J.D.; ALMEIDA, C.C.; DANTAS, V.A.V.; SILVA, B.M.; MORAES, W.S. Efeito da temperatura e do substrato na germinação de sementes de Caesalpinia ferrea Mart. ex Tul. (Leguminosae, Caesalpinoideae) Revista Árvore, v.30, n.4, p.513-518, 2006. http://www.scielo.br/pdf/rarv/ v30n4/31671.pdf

LORENZI, M. Árvores brasileiras; manual de identificação e cultivo de plantas arbóreas nativas do Brasil. Nova Odessa, SP. Editora Plantarum, 2002. 352p.

MAGUIRE, J.D. Speed of germination aid selection and evaluation for seedling emergence and vigour. Crop Science, v.2, p.176-177, 1962.

MEDEIROS FILHO, S.; SILVA, M.A.P.; SANTOS FILHA, M.E.C Germinação de sementes e desenvolvimento de plântulas de Caesalpinia ferrea Mart. ex Tul var. ferrea em casa de vegetação e germinador. Revista Ciência Agronômica, v.36, n.2. p.2003-2008. 2005. http://www.ccarevista. ufc.br/seer/index.php/ccarevista/article/view/269/264

MORRIS, K.; LINKIES, A.; MULLER, K.; ORACZ, K.; WANG, X.; LYNN, J.R.; LEUBNER-METZGER, G.; FINCH-SAVAGE, W.E. Regulation of seed germination in the close Arabidopsis relative Lepidium sativum: A global tissue-specific transcript analysis. Plant Physiology, v.155, p.18511870, 2011. http://www.plantphysiol.org/content/155/4/1851.full.pdf +html

OLIVEIRA-FILHO, A.T. Catálogo das árvores nativas de Minas Gerais Mapeamento e Inventário da Flora Nativa e dos Reflorestamentos de Minas Gerais. 1. ed. Lavras: Editora UFLA, v.1, 2006. 43p.

POZITANO, M.; ROCHA, S.C.S. Caracterização física e germinação de sementes de Senna macranthera. Revista Brasileira de Sementes, v.33, p.777-784, 2011. http://www.scielo.br/pdf/rbs/v33n4/20.pdf

SILVA, E.A.A.; TOOROP, E.P.; VON AELST, A.C.; HILHORST, H.W.M Abscisic acid controls embryo growth potential and endosperm cap weakening during coffee (Coffea arabica cv. Rubi) seed germination. Planta, v.220, n.2, p.251-261, 2004. http://download.springer.com/static/pdf/181/ art\%253A10.1007\%252Fs00425-004-1344-0.pdf?auth66=1410630174 e37e5f068d5419e5eca857118a5fa62d\&ext=.pdf

STATISTICA. STATSOFT, Inc.. Data analysis software system, version 8 2009. www.statsoft.com.

TEIXEIRA， S.P.; CARMELLO-GUERREIRO， S.M.; MACHADO, S.R. Fruit and seed ontogeny related to the seed behavior of two tropical Caesalpinia species (Leguminosae). Botanical Journal of the Linnean Society, v.146, p.57-70, 2004. http://onlinelibrary.wiley.com/doi/10.1111/ j.1095-8339.2004.00313.x/pdf

TEIXEIRA, S.P.; MACHADO, S.R. Storage sites in seeds of Caesalpinia echinata and $C$. ferrea (leguminosae) with considerations on nutrients flow. Brazilian Archives of Biology and Technology, v.51, n.1, p.127-136, 2008. http://www.scielo.br/pdf/babt/v51n1/a16v51n1.pdf

TURNER, S.R.; MERRITT, D. J.; BASKIN, C.C.; DIXON, K.W.; BASKIN, J.M Physical dormancy in seeds of six genera of Australian Rhamnaceae. Seed Science Research, v.15, p.51-58, 2005. http://journals.cambridge.org/action/displayAbstract fromPage $=$ online $\&$ aid $=705008 \&$ fileId $=$ S096025850500005X

VENIER, P.; FUNES, G.; CARRIZO-GARCIA, C. Physical dormancy and histological features of seeds of five Acacia species (Fabaceae) from xerophytic forests of central Argentina. Flora, v.207, p.39-46, 2012. http:// www.sciencedirect.com/science/article/pii/S036725301100154X\# 